\title{
Tożsamość pedagogicznej przestrzeni. Pomiędzy etosem a grq: Refleksje na kanwie wybranych elementów myśli Józefa Tischnera
}

\author{
The Identity of the Educational Space. \\ Between the Ethos of a Game: Reflections \\ on Selected Elements of the Thought of Jozef Tischner
}

\footnotetext{
ABSTRAKT

Artykuł przedstawia analizy dotyczqce przestrzeni pedagogicznej. Punktem wyjścia podjętych badań czyni teksty filozoficzne Józefa Tischnera. Przestrzeń rozumiana jest jako etos, czyli miejsce duchowego wzrastania człowieka. W etosie człowiek odnajduje najpierw samego siebie, potem innych ludzi. Uczy się poznawać i rozumieć świat, który go otacza. W pewnych sytuacjach etos staje się jednak miejscem gry prowadzonej przez innych ludzi. Gra wprowadza zasady obce dla tożsamości człowieka rozumianego jako osoba i podmiot swoich działań moralnych.

Odwołujqc się do filozoficznej refleksji Józefa Tischnera, autor poszukuje odpowiedzi na pytania dotyczqce kształtu współczesnej przestrzeni pedagogicznej. Przestrzeń ta jest zawsze zakorzeniona $w$ jakimś etosie aksjologicznym. Dlatego też bardzo istotne jest odkrywanie tego, jakie wartości rzqdzq ta przestrzeniq, czy jest to 
obszar dialogu, racjonalnej analizy własnego, a zarazem odkrywanego na zewnqtrz siebie świata, czy też jest to obszar przyimujacy postać zdeformowanq, znaczonq lękami, uprzedzeniami, stereotypami baqdź emocjami. Czy tą przestrzeniq kieruje chęć odkrywania prawdy, czy też umiejętność dopasowania się do bezkrytycznie przyjmowanych reguł gry przez „mieszkańców” tej przestrzeni? Co należy czynić, aby pedagogiczna przestrzeń nie nabierała tylko cech totalności, systemowości, standaryzacji, parametryzacji, a pedagog był w dalszym ciqgu "akuszerem prawdy"? Na niektóre z tych pytań autor usiłuje znaleźć odpowiedź, inspirujq̨c się przemyśleniami Józefa Tischnera.

\section{ABSTRACT}

The article presents an analysis of the teaching space. The author makes the starting point of this study the philosophical texts of Jozef Tischner. Space is understood as ethos, as the place of the spiritual growth of man. Man finds his ethos first, then that of other people. He learns to know and understand the world that surrounds it. In some situations, however, the ethos is a place of a game led by other people. The game introduces principles foreign to the identity of the man understood as an entity and his moral actions.

Referring to Jozef Tischner's philosophical reflection, author is trying to find the answers to the questions relating to the shape of the contemporary pedagogical space. This space is always rooted in some axiological ethos. Therefore, it is very important to discover what values govern this space, whether it is a space open for dialogue, for rational self-analysis, and, at this same time, open to the world discovered outside of us, or rather this space assumes a deformed character, marked by fears, prejudices, stereotypes or emotions. Does this space drive us to discover the truth, or is it rather the area where we uncritically accept the rules of the game imposed by others "dwellers" of that space? What should be done in order to prevent the pedagogical space from acquiring the features of totality, systematization, standardization, parameterization? What should be done in order to keep the proper ethos of the pedagogue as a "trumpeter of truth"? Author is trying to find some answers to the above questions seeking an inspiration in Jozef Tischner's thought. 


\section{Etos jako środowisko rozwoju człowieka}

Pośród wielu definicji słowa etos, jedno z jej ujęć - wypracowane przez Martina Heideggera - sprawia wrażenie nieco odmiennego od pozostałych. Nawiązuje ono do opowieści jaką potomnym pozostawił w swych pismach Arystoteles, a którą przytaczam za niemieckim filozofem:

Heraklitowi przypisuje się słowa wypowiedziane do obcych przybyszów, którzy chcieli go odwiedzić. Nadchodząc, zobaczyli go, jak grzał się przy piecu piekarskim. Zatrzymali się zdumieni i to tym bardziej, że Heraklit, widząc ich wahanie, dodawał im odwagi i zapraszał do wejścia słowami: „Tutaj także obecni są bogowie”. [...] W pierwszej chwili, ujrzawszy miejsce pobytu myśliciela, tłum obcych przybyszów staje bezradny i rozczarowany w swej natrętnej ciekawości. Sądzą oni, że powinni spotkać myśliciela w okolicznościach, które w przeciwieństwie do zwykłej wegetacji ludzkiej byłyby pod każdym względem wyjątkowe i osobliwe, toteż miałyby w sobie coś pobudzającego. [...]. Zamiast tego ciekawscy odnajdują Heraklita przy chlebowym piecu. Jest to doprawdy miejsce zwyczaje i niepozorne. [...] Odwiedzający zbierają się do odejścia. Heraklit odczytuje na ich twarzach zawiedzioną ciekawość [...]. Dlatego dodaje im odwagi. Nakłania ich, by weszli, słowami: [...] - tutaj także obecni są bogowie ${ }^{1}$.

Józef Tischner $W$ etyce wartości i nadziei komentując powyższy fragment dodaje, że:

mówiąc „tutaj także”, Heraklit użył słowa ethos. Greckie słowo ethos ma wiele znaczeń. Między innymi wskazuje ono na miejsce, w którym roślina może się rozwijać bez przeszkód, może żyć, przynosić owoc. Także bezpieczna kryjówka dzikiego zwierzęcia jest jego ethosem. Ethos to tyle co „środowisko”, „domostwo”, pole życia wszelkiej istoty żywej. Aby istota żywa mogła przynosić „swój owoc”, musi wpierw znaleźć sobie właściwy ethos. Coś podobnego dzieje się z człowiekiem. Człowiek, aby żyć, rozwijać się i być sobą, także potrzebuje ethosu. Ale ethos człowieka jest szczególny. Wytwarzają go nie tylko powietrze, ziemia, woda, lecz przede wszystkim środowisko ludzkie, inni ludzie. Człowiek poszukuje sobie miejsca wśród ludzi ${ }^{2}$.

Stawiając pytanie o tożsamość pedagogicznej przestrzeni, odnajdujemy więc wskazówkę, która prowadzi nas do odsłonięcia jakiegoś

1 M. Heidegger, List o „humanizmie”, w: M. Heidegger, Znaki drogi, tłum. S. Blandzi, Warszawa 1995, s. 161-162.

2 J. Tischner, Etyka wartości i nadziei, w: D. von Hildebrand, J.A. Kłoczowski, J. Paściak, J. Tischner, Wobec wartości, Poznań 1984, s. 56. 
głębszego sensu naszych poszukiwań. Przestrzeń rozumiana jest w tym wypadku jako etos, czyli miejsce przebywania człowieka, jego miejsce zakorzenienia, miejsce, gdzie czuje się pewnie i bezpiecznie. Gdzie może się rozwijać, wzrastać i poszukiwać odpowiedzi na pytanie o to, co specyficznie ludzkie. Wydaje się jednak, że etos nie jest dany człowiekowi wprost, nie jest jego bezpośrednim atrybutem, cechą, z którą człowiek się rodzi. Etos należy odnaleźć, odsłonić, uświadomić sobie jego istnienie i nasz w nim udział. Jest on bowiem nierozerwalnie związany z poszukiwaniem i odnajdywaniem „spraw boskich". Jest wchodzeniem z nimi w swoisty dialog. Jest miejscem przebywania człowieka.

[Etos] oznacza pobyt, miejsce zamieszkiwania. Słowo to jest nazwaniem otwartego obszaru, gdzie mieszka człowiek. Otwarta przestrzeń jego miejsca pobytu pozwala przejawiać się temu, co się zbliża ku istocie człowieka i co, dochodząc, przebywa w jej pobliżu. Pobyt człowieka obejmuje sobą i ochrania nadejście tego, do czego człowiek w swej istocie należy³.

Ów etos nie jest jednak miejscem pasywnego przebywania człowieka. W etosie toczy się nieustanny dialog. Najpierw człowieka z sobą samym, potem $\mathrm{z}$ innym człowiekiem i jego wytworami „zamkniętymi” w postaci świata kultury, dalej z otaczającym go światem i jego Stwórcą. Co jest celem i sensem owego dialogu? Jest nim „odsłanianie spraw boskich". A więc poszukiwanie odpowiedzi na pytanie o sens. $\mathrm{O}$ sens własnego życia i życia innych ludzi. O sens istnienia świata i tego wszystkiego, co na ten świat się składa. Jest to swego rodzaju „przekopywanie” codzienności. To swoista praca „archeologiczna” poszukiwanie egzystencjalnego arché. W tej swojej pracy poszukiwawczej człowiek napotyka na swojej drodze innych ludzi ${ }^{4}$.

3 M. Heidegger, List o, humanizmie”, dz. cyt., s. 161.

4 W jednej ze swych prac pisałem: „Będąc bytem-w-sobie odkrywam, iż wchodzę z drugim nie tylko w jakąś relację poznawczą, ale również przestrzenną. Jestem w jakimś miejscu. Drugi jest obok mnie w innym miejscu. Greckie topos wyraża miejsce w znaczeniu przestrzeni fizykalnej. Najpierw więc jestem jako byt-w-siebie jako jeden $\mathrm{z}$ wielu bytów zajmujących określone miejsce - topos. Drugi byt znajduje się w określonej odległości. Może znajdować się dalej lub bliżej. [...]. Jeden byt-w-sobie i drugi byt-w-sobie mogą się od siebie oddalać albo do siebie zbliżać. Owo oddalenie bądź zbliżenie może posiadać określony walor czasowy. Możemy zbliżyć się do siebie na zawsze bądź deklarować, iż nigdy więcej nie zbliżymy się do siebie tak, by się zobaczyć. Paradoks tkwi w tym, iż często miejsce w przestrzeni fizykalnej, geograficznej 


\section{Dialogiczny charakter etosu według Józefa Tischnera}

W dialogu doświadcza się spotkania. „Spotkanie z drugim jest na początku wszelkiego doświadczenia świata. Można powiedzieć, że drugi jest kategorią a priori, dzięki której możliwy jest tak zwany obiektywny świat" ${ }^{\prime \prime}$. Etos więc nie jest pusty, nie jest niezamieszkały, przynależy do niego człowiek wraz ze wszystkimi własnymi sprawami. To on jest warunkiem koniecznym istnienia etosu. Bez człowieka nie byłoby etosu. Należy jednak dodać, że nie chodzi tu o zwykłą fizyczną obecność człowieka obok drugiego człowieka. Tu chodzi o obecność etyczną, która rodzi się w sytuacji bycia człowieka wobec drugiego człowieka, a w konsekwencji - bycia jednego dla drugiego bądź jednego przeciw drugiemu. Owo bycie wobec i bycie dla (bądź przeciw) naprowadza nas na wymiar etyczny przestrzeni ludzkiego przebywania. „Drugi jest mi potrzebny, bo budzi moją świadomość wolności. Jestem wolny wobec drugiego, ale to w końcu ja jestem wolny. Jestem wierny, mogę być wierny, ale to ja mogę być wierny drugiemu. [...] Drugi jest akuszerem pewnej prawdy, którą odkrywam w sobie"6.

Etos jawi się więc jako miejsce współprzebywania z drugim człowiekiem. Jest to jednak specyficzny rodzaj bycia, w którym w sposób konieczny muszę się otworzyć na drugiego człowieka poprzez spotkanie i dialog.

Spotkanie jest wydarzeniem. Spotkanie pociąga za sobą istotną zmianę w przestrzeni obcowań. Ten, kto spotyka, wykracza, transcenduje - poza siebie w podwójnym sensie tego słowa: ku temu, komu może dać świadectwo (w stronę innego) i ku temu, przed kim może złożyć świadectwo (przed Nim - tym, kto żąda świadectwa). Dlatego należy powiedzieć: spotkać, to do-świadczyć Transcendencjī.

Etos jako miejsce ludzkiego współ-przebywania, a zarazem współ-odpowiadania jednego człowieka za drugiego, jest przestrzenią,

nie pokrywa się z miejscem jakie czynię dla drugiego człowieka w przestrzeni duchowej”. A. Ryk, Pedagogika dramatu. Poszukiwania antropologiczno-metodologiczne, Kraków 2008, s. 92.

5 J. Tischner, Spotkanie. Z ks. Józefem Tischnerem rozmawia Anna Karoń-Ostrowska, Kraków 2003, s. 129.

6 Tamże, s. 133.

7 J. Tischner, Filozofia dramatu, Kraków, 2006, s. 27. 
która stale stawia wyzwania. Każdy bowiem spotkany człowiek jest jakimś zadaniem do wypełnienia. Jest jakimś zobowiązaniem, wobec którego stajemy. Wspól-przebywający ludzie nie są jedynie grupą jakichś jednostek tworzących społeczne zbiorowości, realizujących określone zadania, pełniących określone role zawodowe, rodzinne itp. Przede wszystkim są istotami etycznymi, współodpowiedzialnymi za samych siebie i za świat, który tworzą. Tworzyć świat specyficznie ludzki, to tworzyć przestrzeń wzajemnej współodpowiedzialności za trwałość i przekazywanie wartości specyficznie ludzkich.

Tylko ten, kto doświadczył spotkania może mówić, że doświadczył źródłowo jakiegoś konkretnego dobra i zła, jakiejś tragiczności, jakiejś wolności oraz głosu imperatywu kategorycznego, który od drugiego doszedł ku niemu. Tylko ten, kto spotkał, może szczerze poświęcić siebie. Poza spotkaniem wszystkie wyżej wymienione pojęcia są wyprane $z$ doświadczenia ${ }^{8}$.

\section{Przestrzeń pedagogiczna jako kategoria etosu}

Spróbujmy na podstawie powyższych odniesień zbudować w tym duchu jakieś wstępne choćby rusztowania myślenia o tożsamości pedagogicznej przestrzeni. Pierwszy wymiar tego myślenia odsłania się w przekonaniu, że przestrzeń pedagogiczna, bardziej niż miejscem o charakterze fizykalnym, materialnym, jest rodzajem etosu. A wiec przestrzenią o charakterze duchowym. Tożsamość tej przestrzeni jest nadawana przez współ-przebywające w niej podmioty, wzajemnie za siebie odpowiedzialne. Owa odpowiedzialność wypływa z przekonania o istnieniu stałych i niezmiennych wartości obecnych w ludzkim życiu. Tymi wartościami są przede wszystkim prawda i dobro. Ich poszukiwanie, a zarazem dążenie do ich realizacji, jest wpisane w samą naturę człowieka. Kolejną ważną cechą charakteryzującą pedagogiczną przestrzeń jest dialogiczność i spotkanie. Podmioty pedagogicznej przestrzeni nie są bowiem bezwładnymi, obojętnymi podmiotami, ale istotami egzystującymi w świecie, posiadającymi własną historię, dziejowość, świat przeżywany, własny zbiór myśli, dążeń i pragnień. Każdy z nich posiada własną, osobową, a zarazem osobistą przestrzeń życia, w której i poprzez którą wchodzi w dialog, spotyka się z innymi podmiotami, osobami.

8 J. Tischner, Myślenie wedtug wartości, Kraków 1982, s. 499. 
W pedagogicznej przestrzeni człowiek z jednej strony poszukuje, a z drugiej - odnajduje samego siebie. Poszukuje odpowiedzi na pytanie dotyczące własnej tożsamości i własnego miejsca w świecie. Stawia też pytania o granice i możliwości własnego (indywidualnego), a zarazem ludzkiego poznania. W wyniku poznawczej aktywności człowieka rodzi się w nim jakiś obraz świata, zarówno jego własnego (wewnętrznego), jak i zewnętrznego (świata kultury i świata przyrody). Jednym $z$ istotnych elementów tego obrazu, a równocześnie ważnym składnikiem pedagogicznej przestrzeni, jest rodzący się jakiś aksjologiczny horyzont. Jakiś świat wartości, wewnętrzne przekonanie, zarówno pojedynczego podmiotu, jak i całych zbiorowości, staje się cechą konstytutywną samego procesu wychowania. Staje się jego nieodłączną częścią.

Taką cechą jest również intencjonalność. Wychowuje się ze względu na coś, czy do czegoś, ku czemuś. Realizacja danych wartości w życiu człowieka (bądź ich brak) rodzi jakąś tragiczność, jakiś dramat w wychowaniu człowieka. W pracy Pedagogika dramatu. Poszukiwania antropologiczno-metodologiczne pisałem:

Punktem wyjścia w pedagogice dramatu staje się więc świat przeżywany podmiotów wychowania (wychowawcy i wychowanka) w sytuacji tego, co w nich aktualnie dzieje się. Owo dzianie się jest charakterystyczne zarówno dla tego, kogo w tradycyjnej pedagogice nazywaliśmy wychowawcą i wychowankiem. Jest to niejako podstawowa kategoria ontyczna łącząca obydwa podmioty wychowania. To, co dzieje się w owych światach przeżywanych w odniesieniu do licznych kontekstów społeczno-kulturowych, jak i w odniesieniu historycznym, staje się przedmiotem rozumienia/poznawania tożsamości podmiotów wychowania. Wychowanie jawi się więc jako sytuacja wzajemnego współzaangażowania obydwu podmiotów w rozumienie i współtworzenie tożsamości własnych światów przeżywanych. Podmioty dążą do rozumienia tego, co dzieje się - w nich samych, pomiędzy nimi. W relacji do systemów abstrakcyjnych, w odniesieniu do świata natury/przyrody. Rozumienie jawi się więc jako podstawowa aktywność podmiotu w obszarze wychowania ${ }^{9}$.

Przestrzeń pedagogiczna jest więc miejscem rozumienia tak wychowawcy, jak i wychowanka - ich światów wewnętrznych, a zarazem świata jako takiego ${ }^{10}$. W przestrzeni wychowawczej rozumienie po-

9 A. Ryk, Pedagogika dramatu. Poszukiwania pedagogiczno-antropologiczne, Kraków 2008, s. 99-100.

10 „W naszym przypadku przedmiotem rozumienia czynimy na pierwszym miejscu świat przeżywany. [...]. Najpierw wychowawcy, jako tego, kto ma 
przedza więc pedagogiczne działanie, które nie jest tylko wynikiem bycia i zaangażowania człowieka w świecie zewnętrznym, ale również, a może właśnie przede wszystkim, jest efektem zaangażowania podmiotu (wychowawcy, wychowanka) w swój własny świat wewnętrzny/ świat przeżywany. Pedagogiczna przestrzeń nabiera więc swoistego dualnego, immanentno-transcendentnego wymiaru. Wewnętrzność i zewnętrzność pedagogicznej przestrzeni nie są zamkniętymi względem siebie ilościowymi, statycznymi zbiorami, myśli, doznań, spostrzeżeń. Ich wzajemny stosunek do siebie ma charakter dialogiczny ${ }^{11}$. Toczy się stale jakiś wewnętrzny dialog podmiotu samego $\mathrm{z}$ sobą $\mathrm{w}$ pedagogicznej przestrzeni obcowań z innymi. Nie zawsze jednak ów dialog prowadzi podmioty wychowania do otwarcia się na siebie samych, na drugiego, na prawdę. Zdarza się, że człowiek unika dialogu, wycofuje się, chowa się, zamyka się. Tischner konstatował: „Człowiekiem z kryjówki jest ten, kto cierpi na chorobę nadziei: jego nadzieją rządzi zasada ucieczki od ludzi. Tkwi ona korzeniami w jakimś mniej lub bardziej świadomym lęku przed ludźmi i światem" ${ }^{2}$.

Okazuje się więc, że pedagogiczna przestrzeń naznaczona jest nie tylko światem dialogu, racjonalnej analizy własnego, wewnętrznego, a zarazem otaczającego świata, ale również może ona przybierać postać zdeformowaną lękami, uprzedzeniami, stereotypami, emocjami.

rozumieć. A nie mogę rozumieć drugiego, i co za tym idzie prowadzić go do rozumienia, nim wpierw nie będę starał się rozumieć siebie w różnych relacjach, kontekstach i uwikłaniach. Potrzeba więc postawy autorefleksji. Uczynienia z siebie (podmiotu) - przedmiotu rozumienia. Muszę więc jako podmiot stanąć wobec własnego świata przeżywanego i zapytać się o dwie rzeczy. Jaki jest mój własny świat przeżywany oraz jak i przez co, przez kogo, w jakim celu został on ukształtowany". A. Ryk, Pedagogika dramatu, dz. cyt., s. 100.

11 „Człowiek posiada więc zdolność przechodzenia z poziomu sceny dramatu świata rzeczy na poziomie dialogu - do świata charakterystycznego dla poziomu myśli, idei, ducha. O ile w pierwszym przypadku dominuje logika indukcyjno-dedukcyjna w wyjaśnianiu rzeczywistości, logika przyczynowo-skutkowa, o tyle w drugim przypadku mamy do czynienia z logiką dramatu nieposiadającą żadnych rygorów bezwzględnej weryfikacji bądź falsyfikacji. Kiedy owa logika się unaocznia, przychodzi moment, kiedy staję wobec drugiego w jakiejś szczególnej sytuacji. Tą sytuacją jest prawda. Nie posiadam już maski, tak niezbędnej w codziennym życiu społecznym. [...] Gdy moje jestem-wobec-drugiego jest zarazem jestem-wobec-prawdy, rozpoczyna się proces bycia-dla-drugiego, a równocześnie bycia-dla-siebie”. A. Ryk, Pedagogika dramatu, dz. cyt., s. 93.

12 J. Tischner, Ludzie z kryjówek, w: J. Tischner, Myślenie wedtug wartości, Kraków 2011, s. 455-456. 
Wówczas zamiast dialogu poszukującego prawdy pojawia się gra. Jest ona głęboko zakorzeniona $\mathrm{w}$ doświadczeniu człowieka. Brać udział w egzystencji, znaczy grać swoją rolę. Gra się role zawodowe, rodzinne, czasami gra się rolę ojca, matki, dziecka itp. Gra stwarza jednak swoiste napięcie pomiędzy wymogami prawdy a wymogami gry. Nie zawsze muszą być one ze sobą tożsame. I najczęściej tak nie jest. Ten, kto poszukuje prawdy, dąży do niej jest autentycznie i odpowiedzialnie. Ten, kto gra, dostosowuje swój sposób postępowania i obcowania z drugim do obowiązujących zasad gry. Nie są one jednak determinowane przez tożsamość prawdy jako wartości, ale przez grupy interesów i zachowań: dominację, władzę, chęć panowania nad drugim. Przestrzeń pedagogiczna staje się demagogiczna. Demos zyskuje przewagę nad prawdą. Sam demos uzurpuje sobie prawo do jej posiadania i wyrażania. Demos staje w opozycji do prawdy, gdyż ta narzuca swoje własne „reguły gry”. To demos skazuje Sokratesa na śmierć. To demos krzyczy do Piłata w procesie Chrystusa: „Ukrzyżuj Go!”. Demos jest ślepy, a kiedy objawia się Prawda, umywa ręce ${ }^{13}$. $\mathrm{W}$ pedagogicznej przestrzeni stale więc ma miejsce napięcie pomiędzy prawdą a grą ${ }^{14}$. „Klasyczna definicja prawdy została odrzucona,

13 W jednym ze swych wcześniejszych tekstów konstatowałem: „Czym jest bóstwo demosu? Jest ekspresją ludzkich pożądliwości, ustrukturyzowaną machiną państwa w pliki przepisów, zasad i norm, które mają regulować myślenie i działanie ludzkiej jednostki. Bano się Sokratesa, bo łamał i niszczył utarte sposoby rozumienia i interpretowania rzeczywistości, pokazywał obłudę i cyniczną grę nazywaną często edukacją, wychowaniem czy dobrem społeczności. Nie bał się narażać dla poszukiwania i odsłaniania prawdy, do której dotarcie jest zawsze wysiłkiem”. A. Ryk, Między teoriq a praktykq wychowania. Ujęcia - koncepcje - inspiracje, Kraków 2014, s. 22-23.

14 „Nasz dyskurs pedagogiczny lub psychagogiczny jest retoryką, mówieniem z pozycji kogoś, kto chce przechytrzyć bliźniego. Właśnie dlatego sztuka sofisty stanowi problem, wobec którego musi określić się prawdziwa mowa prawdy, dyskurs filozoficzny. Retoryka, od której nie jest wolna żadna mowa i która próbuje przezwyciężyć dyskurs filozoficzny, stawia mowie opór (to jest wprowadza do niej pedagogię, demagogię, psychagogię). Nie staje ona naprzeciw Innego, lecz podchodzi do niego z ukosa, choć nie traktuje go jak rzecz, bo pozostaje mową i mimo wszystkich swoich sztuczek zwraca się do innego, zabiega o jego «tak». Ale specyficzna natura retoryki [...] polega na niszczeniu wolności. Dlatego jest przemocą we właściwym sensie, to znaczy niesprawiedliwością. Przemocą, która gwałci nie coś bezwładnego - nie byłaby to przemoc - lecz gwałci wolność, która właśnie jako wolność powinna być nienaruszalna. Retoryka umie ujmować wolność za pomocą kategorii zdaje się ją traktować, jako przyrodę, zadając wewnętrznie sprzeczne pytanie: 
ponieważ nie ma już obiektywnej rzeczywistości, do której miałaby się stosować. Wszelka rzeczywistość jest kreślona przez grę [...]. Tak więc cały nasz świat jest światem utworzonym przez grę"15.

Demos buduje zatem własny świat, oparty nie na zasadach Prawdy, ale na własnych prawach i prawdach. Ta swoista, idiomatyczna konstrukcja po pewnym czasie staje się powszechnie akceptowana i obowiązująca. Pedagogiczna przestrzeń nabiera cech totalności, całości, systemowości, kontrolowalności, standaryzacji, parametryzacji, hermetyczności. Pedagog staje się urzędnikiem, kontrolerem, funkcjonariuszem, arbitrem. Staje się „człowiekiem z kryjówki”:

Dookoła kryjówki rozpościera się przestrzeń możliwych obcowań z drugimi. Każdy człowiek organizuje w sposób mniej lub bardziej świadomy duchową przestrzeń obcowania z ludźmi, ale u pielgrzymujących organizacja ta jest dość luźna, odpowiadająca realnym potrzebom drugich i własnym możliwościom ich zaspokojenia. Natomiast u ludzi z kryjówek jest ona sztywna, skostniała, jakby raz na zawsze ustalona, a jej główne zarysy są trudno uchwytne dla drugich. Ktokolwiek znalazł się w polu obcowania z człowiekiem z kryjówki, poczuł pod stopami ziemię niepewną; czegoś się tu od niego oczekuje, ale nie wiadomo bliżej czego. Im głębiej wszedł człowiek w swą kryjówkę, tym ważniejsze stają się dla niego wszelkie spotkania $z$ innymi, ale też tym bardziej skostniały i trudny do uchwycenia jest ich styl. Raz dąży do zjednania sobie ludzi, to znowu do oddalenia ich od siebie, raz się ich bezpodstawnie oskarża, kiedy indziej przechodzi się do bezpodstawnego oskarżania siebie, jakby się chciało sprowokować uniewinnienie. Wszystko to ma określony cel: człowiek stara się utrzymać drugiego człowieka w bezpiecznym oddaleniu od ściany kryjówki. W tym właśnie celu prowadzi z nim swoistą grę - grę o zawładnięcie ${ }^{16}$.

$$
* * *
$$

W tym punkcie rozważań rodzi się pytanie: jaka jest tożsamość pedagogicznej przestrzeni pomiędzy prawdą a grą? Czy jako podmioty, a zarazem przedmioty ludzkiego i jakiegoś społecznego dramatu, jesteśmy w stanie samodzielnie kreować relacje będące rdzeniem naszych wzajemnych odniesień? Jaka jest rola jednostki, osoby,

jaka jest natura tej wolności”. E. Lévinas, Catośc i nieskończoność. Esej o zewnętrzności, tłum. M. Kowalska, Kraków 2002, s. 68.

15 J. Tischner, Spór o istnienie cztowieka, Kraków 1999, s. 110.

16 J. Tischner, Ludzie z kryjówek, w: J. Tischner, Myślenie wedtug wartości, dz. cyt., s. 457. 
a jaka rola społeczeństwa, państwa, polityki w kształtowaniu etosu wzajemnej odpowiedzialności za samych siebie i za społeczności, które współtworzymy? Pojawiające się pytania z pewnością jeszcze długo pozostaną bez pełnej odpowiedzi. Jak zauważa bowiem Tischner, jedną z cech charakterystycznych dla naszej egzystencji jest błądzenie w żywiołach prawdy, dobra i piękna ${ }^{17}$. I choć wartości te pozostają swoistymi żywiołami, to jednak dla wielu one wciąż istnieją. I to napawa wiarą i nadzieją na odnalezienie pedagogicznej przestrzeni między etosem a grą.

\section{Bibliografia}

Heidegger M., List o „humanizmie, w: M. Heidegger, Znaki drogi, tłum. J. Tischner i in., Aletheia, Warszawa 1995, s. 129-168.

Lévinas E., Catość i nieskończoność. Esej o zerwnętrzności, tłum. M. Kowalska, Wydawnictwo Naukowe PWN, Kraków 2002.

Ryk A., Między teoriq a praktykq wychowania. Ujęcia-koncepcje - inspiracje, Iris Studio, Kraków 2014.

Ryk A., Pedagogika dramatu. Poszukiwania antropologiczno-metodologiczne, Wydawnictwo Naukowe Akademii Pedagogicznej, Kraków 2008.

Tischner J., Etyka wartości i nadziei, w: D. von Hildebrand, J.A. Kłoczowski, J. Paściak, J. Tischner, Wobec wartości, W Drodze, Poznań 1984, s. 55-149.

Tischner J., Filozofia dramatu, Znak, Kraków 2006.

Tischner J., Ludzie z kryjówek, w: J. Tischner, Myślenie wedtug wartości, Znak, Kraków 2011, s. 454-469.

Tischner J., Myślenie wedtug wartości, Znak, Kraków 1982.

Tischner J., Spotkanie. Z ks. Józefem Tischnerem rozmawia Anna Karoń-Ostrowska, Znak, Kraków 2003.

Tischner J., Spór o istnienie człowieka, Znak, Kraków 1999.

\section{ADRES DO KORESPONDENCJI:}

Dr hab. Andrzej Ryk, prof. UP

Uniwersytet Pedagogiczny im. Komisji Edukacji Narodowej

Wydział Pedagogiczny

Instytut Nauk o Wychowaniu

aryk@poczta.fm

17 Por. J. Tischner, Filozofia dramatu, dz. cyt., s. 83-216. 